\title{
DANO EXISTENCIAL E A RELAÇÃO DE TRABALHO: REFLEXÃO PARA
} EFETIVAÇÃO DE DIREITOS

\author{
Tatiane Campelo da Silva Palhares ${ }^{1}$
}

\section{RESUMO}

O propósito deste trabalho é enfrentar o seguinte problema: como se constitui o dano existencial e quais as implicações na relação de trabalho da administração pública? O presente artigo analisa a temática do dano existencial causado ao trabalhador contratado para prestar serviço na administração pública. Compreende-se o dano existencial como a sistemática conduta patronal em impor jornadas de trabalho além dos limites legais. Adota-se no presente trabalho o método qualitativo e procedimento exploratório utilizado na coleta de dados bibliográfico, doutrinário, documental e legal.

Palavras-Chave: Trabalhador; Administração Pública; Dano Existencial; Contratação; Trabalho.

\section{EXISTENTIAL DAMAGE AND WORK RELATIONSHIP: REFLECTION FOR THE ENTITLEMENT OF RIGHTS}

\begin{abstract}
The purpose of this paper is to address the following problem: how is existential damage constituted and what are the implications of the public employment relationship? The present article analyzes the existential damage caused to the hired worker to provide service in the public administration. Existential damage is understood as the systematic conduct of employers in imposing working hours beyond the legal limits. The qualitative method and exploratory procedure used in the collection of bibliographic, doctrinal, documentary and legal data are adopted in the present work.
\end{abstract}

Keywords: Worker; Public administration; Existential Damage; Hiring; Job.

\footnotetext{
1 Doutoranda em Direito Constitucional pela Universidade de Fortaleza - UNIFOR. Professora universitária do Centro Universitário de Ensino Superior do Amazonas - CIESA. tatianepalhares@hotmail.com
} 


\section{INTRODUÇÃO}

A terceirização é um instituto oriundo da ciência da administração que visa a redução de custos bem como a especialização das atividades empresariais, na medida em que permite a maior concentração da empresa em sua atividade-fim. Para a qual foi estabelecida, trespassando a outras empresas normalmente as atividades-meio, que não constituem o foco principal de sua existência (ZOCKUN, 2014, p.58).

Assim, com relação às atividades terceirizadas, a jurisprudência e a doutrina costumam diferenciá-la em atividades-meio e atividades-fim. Costuma-se entender por atividades-fim aquelas relacionadas com o objetivo final da empresa, e atividades-meio aquelas referentes ao suporte ou apoio necessário para o processo produtivo. $\mathrm{O}$ movimento da terceirização surgiu após a Revolução Industrial. No começo do século XX os Estados Unidos e a Alemanha despontaram como grandes potências industriais. O setor metalúrgico era o que continha o maior número de trabalhadores, e a indústria automobilística foi pioneira na criação do processo de produção (SANTOS, 2014, p. 67).

Compreende-se o dano existencial como a sistemática conduta patronal em impor jornadas de trabalho além dos limites legais, causando verdadeira anulação do indivíduo que deixa de vivenciar atividades recreativas, culturais, esportivas, perdendo considerável parte do convívio familiar, sendo reduzido a mera ferramenta de trabalho (MOLILA, 2015, p. 15).

Assim, o presente artigo objetiva analisar as implicações do dano existencial a partir das relações de trabalho das terceirizações no âmbito da administração pública, e, para isso adotou-se o método qualitativo, ao qual parte de aspectos subjetivos e amostras mais restritas. A pesquisa de nível explicativa com procedimento exploratório utilizado na coleta de dados bibliográfica, doutrinária, documental e legal. A problemática do trabalho diz respeito as implicações do dano existencial causado pela terceirização na administração pública, haja vista que determinados fatores, bem como as longas jornadas de trabalho, causam verdadeira anulação do trabalhador enquanto indivíduo.

Rev. de de Direitos Fundamentais Nas Relações Do Trabalho, Sociais E Empresariais | e-ISSN: 2525-9903 | Goiânia| v. 5 | n. 1 | p. 18-34| Jan/Jun. 2019 
O trabalho será apresentado com a seguinte estrutura: 1. Administração Pública e seus preceitos doutrinários, o qual entende-se, doutrinariamente, que a organização da administração pública, no Brasil, segue as linhas tracejadas pelo Decreto-lei 200/1967, de cujos dispositivos se extrai a divisão da Administração em direta e indireta. O que significa dizer que a Administração direta é composta por órgãos integrantes dos entes federativos, bem como: a União, os Estados, o Distrito Federal e os Municípios. Com esse entendimento e com base no Decreto mencionado, entende-se que tais pessoas jurídicas permitem o surgimento de outras entidades administrativas, que compõem a Administração indireta, bem como: autarquias, fundações públicas, empresas públicas e sociedades de economia mista. Estas duas últimas recaem sobre o entendimento de pessoas jurídicas de direito privado, assim, não integrando o conceito de Fazenda Pública, salvo se estiverem na atividade de serviço público de interesse público; 2 Conceituação e histórico da terceirização, entende-se que a terceirização é um instituto oriundo da ciência da administração que visa a redução de custos bem como a especialização das atividades empresariais; 3- Dano existencial e seus desdobramentos teóricos, destacando-se que as longas jornadas de trabalho e ausência do convívio familiar causam o que se reconhece como dano existencial.

\section{ADMINISTRAÇÃO PÚBLICA E SEUS PRESSUPOSTOS DOUTRINÁRIOS}

Segundo Diógenes Gasparini (2004, p. 42), a administração pública se define por critérios negativista ou residual, segundo o qual é toda atividade do Estado, excluída a legislativa e jurisdicional; o formal, orgânico ou subjetivo, em que administração é um complexo de órgãos responsáveis por funções administrativas; por fim, o critério material ou objetivo que define como um complexo de atividades concretas e imediatas desempenhadas pelo Estado, sob os termos e condições da lei, visando ao atendimento da coletividade.

Jose dos Santos Carvalho Filho (2009, p.10), destaca dois enfoques: sentido objetivo, segundo o qual a administração consiste na própria atividade administrativa exercida pelo Estado, por seus órgãos e agentes; o sentido subjetivo que define como um conjunto de órgãos de que se vale o Estado para atingir os fins desejados.

Rev. de de Direitos Fundamentais Nas Relações Do Trabalho, Sociais E Empresariais | e-ISSN: 2525-9903 | Goiânia| v. 5 | n. 1 | p. 18-34| Jan/Jun. 2019 


\section{DANO EXISTENCIAL E A RELAÇÃO DE TRABALHO: REFLEXÃO PARA EFETIVAÇÃO DE DIREITOS}

Entende-se doutrinariamente que a organização da administração pública, no Brasil, segue as linhas tracejadas pelo Decreto-lei 200/1967, de cujos dispositivos se extrai a divisão da Administração em direta e indireta. O que significa dizer que a Administração direta é composta por órgãos integrantes dos entes federativos, bem como: a União, os Estados, o Distrito Federal e os Municípios. Com esse entendimento e com base no Decreto mencionado, entende-se que tais pessoas jurídicas permitem o surgimento de outras entidades administrativas, que compõem a Administração indireta, bem como: autarquias, fundações públicas, empresas públicas e sociedades de economia mista. Estas duas últimas recaem sobre o entendimento de pessoas jurídicas de direito privado, assim, não integrando o conceito de Fazenda Pública, salvo se estiverem na atividade de serviço público de interesse público. Ademais destaca-se que:

\footnotetext{
Ora, se a expressão Fazenda Pública identifica-se com as pessoas jurídicas de direito público, somente estão nela abrangidos a União, os Estados, os Municípios, o Distrito Federal e suas respectivas autarquias e fundações públicas A esse rol de pessoas jurídicas de direito público acrescem as agências, às quais se tem atribuído a natureza jurídica de autarquias especiais, significando dizer que tais agências se constituem de pessoas jurídicas de direito público destinadas a desempenhar atividade pública. As agencias podem ser executivas ou reguladoras. As primeiras consistem em entidades dotadas de competência para o “...desempenho direto de atividade administrativas, inclusive com atribuição de tarefas materiais, mormente no âmbito do desempenho daquilo que, no âmbito das concepções continentais, se considera como função pública e serviços públicos, mas eventualmente também no tocante a atividade econômica propriamente dita. As agências executivas são autarquias e fundações que assim passam a ser consideradas quando celebram contrato de gestão com a Administração direta, com o objetivo de fixar metas de desempenho para entidade, na forma do art. $37, \S 8^{\circ}$, da Constituição Federal (CUNHA, 2016, p.6).
}

Com esse entendimento, verifica-se que as autarquias ou fundações já existentes, ao celebrarem o referido contrato de gestão com a Administração direta, passam a ostentar a natureza de agências executivas, que são, em essência, autarquias especiais. Já as agências reguladoras, originalmente criadas por lei com personalidade jurídica própria, destinam-se a tarefa normativa, podendo disciplinar questões nas quais a Administração Pública exerça poder de polícia. O que importa deixar evidente é que o conceito Fazenda Pública abrange a União, os Estados, o Distrito Federal, os Rev. de de Direitos Fundamentais Nas Relações Do Trabalho, Sociais E Empresariais | e-ISSN: 2525-9903 | Goiânia| v. 5 | n. 1 | p. 18-34| Jan/Jun. 2019 
Municípios e suas respectivas autarquias e fundações públicas, sendo certo que as agências executivas ou reguladoras, por ostentarem a matriz de autarquias especiais, integram igualmente o conceito de Fazenda Pública, constituídas na forma da Lei 11.107, de 6 de abril de 2005, em razão da formação de consórcio público (CUNHA, 2016, p.8). Resta destacar que:

\begin{abstract}
A associação pública integra o conceito de Fazenda Pública, estão excluídas do conceito Fazenda Pública as sociedades de economia mista e as empresas públicas. Embora integrem a Administração Pública indireta, não ostentam natureza de direito público, revestindo-se da condição de pessoas jurídicas de direito privado, a cujo regime estão subordinadas. Então, quando se alude à Fazenda Pública, na expressão não estão inseridas as sociedades de economia mista nem as empresas públicas, sujeitas que são ao regime geral das pessoas jurídicas de direito privado (CUNHA, 2016, p.8).
\end{abstract}

Com isso, verifica-se que no âmbito da administração pública o uso de atos administrativos em face da discricionariedade administrativa revela-se como algo sindicável para as ações probas e jutas de seus administradores. Logo destaca-se o julgado - STJ, RMS 20.271/GO 2005/0105.910-7, 1. ${ }^{\text {a }}$ T., rel. Min. Luiz Flux, j. 26.05.2009, DJ 06.08.2009, acesso em 15.06.2017:

\begin{abstract}
Os atos discricionários legitimam espaço de liberdade para o administrador, insindicável pelo Poder Judiciário, porquanto nessas hipóteses interditada a intervenção no mérito do ato administrativo. É cediço na doutrina que: '[...] Já se tem reiteradamente observado, com inteira procedência, que não há ato propriamente discricionário, mas apenas discricionariedade por ocasião da prática de certos atos. Isto porque nenhum ato é totalmente discricionário, dado que, conforme afirma a doutrina prevalente, será sempre vinculado com relação ao fim e à competência, pelo menos. Com efeito, a lei sempre indica, de modo objetivo, quem é competente com relação à prática do ato - e aí haveria inevitavelmente vinculação. Do mesmo modo, a finalidade do ato é sempre e obrigatoriamente um interesse público, donde afirmarem os doutrinadores que existe vinculação também com respeito a este aspecto. [...] Em suma: discricionariedade é liberdade dentro da lei, nos limites da norma legal, e pode ser definida como: 'A margem de liberdade conferida pela lei ao administrador a fim de que este cumpra o dever de integrar com sua vontade ou juízo a norma jurídica, diante do caso concreto, segundo critérios subjetivos próprios, a fim de dar satisfação aos objetivos consagrados no sistema legal'. [...] Nada há de surpreendente, então, em que o controle judicial dos atos administrativos, ainda que praticados em nome de alguma discrição, se estenda necessária e insuperavelmente à investigação dos motivos, da finalidade e da causa do ato. Nenhum empeço existe a tal
\end{abstract}

Rev. de de Direitos Fundamentais Nas Relações Do Trabalho, Sociais E Empresariais | e-ISSN: 2525-9903 | Goiânia| v. 5 | n. 1 | p. 18-34| Jan/Jun. 2019 
proceder, pois é meio - e, de resto fundamental - pelo qual se pode garantir o atendimento da lei, a afirmação do direito. [...] Assim como ao Judiciário compete fulminar todo o comportamento ilegítimo da Administração que apareça como frontal violação da ordem jurídica, compete-lhe, igualmente, fulminar qualquer comportamento administrativo que, a pretexto de exercer apreciação ou decisão discricionária, ultrapassar as fronteiras dela, isto é, desbordar dos limites de liberdade que lhe assistiam, violando, por tal modo, os ditames normativos que assinalam os confins da liberdade discricionária' (Celso A. B. de Mello, Curso de direito administrativo, 15. ed., Malheiros, p. 395-396 e 836-837). 5. Deveras, contexto fático encartado nos autos denota a ausência de direito líquido e certo da impetrante, ora recorrente, a uma: porque o juiz, ora impetrado, no exercício de competência discricionária, nenhuma ilegalidade praticou ao nomear interventor, imparcial para administração do cartório em comento, a fim de resguardar o bom andamento das investigações acerca do oficial titular; a duas: porque a impetrante, ora recorrente, é casada com o oficial titular, então afastado por supostas irregularidades cartorárias e seria difícil a mesma colaborar na devassa a ser realizada na serventia, em especial quando as provas apresentadas são contrárias ao seu esposo e filho, escrevente no referido cartório e acusado de falsidade no reconhecimento de firma. 6. In caso, o Tribunal a quo decidiu em consonância com o preceito legal (art. 36, § 1. ${ }^{\text {o }}$, da Lei 8.935/94), [...] o magistrado agiu com discricionariedade, entre várias possibilidades de solução, acolheu a que melhor correspondia, no caso concreto, ao desejo da lei (fls. 103/104). 7. Recurso ordinário desprovido" (STJ, RMS 20.271/GO 2005/0105.910-7, 1. ${ }^{\mathrm{a}}$ T., rel. Min. Luiz Fux, j. 26.05.2009, DJ 06.08.2009).

O interesse público concretiza o nível de desigualdade entre a esfera administrativa e as demais esferas. O nível de desigualdade é ofuscado por um aparente aumento do quadro de servidores contratados, todavia, na contramão da oferta surge a cobrança por jornadas excessivas de trabalho dos terceirizados.

\subsection{Interesse Público: Análise no âmbito da administração pública.}

Interesse público é algo que pode ser relacionado ao "bem comum", e não ao interesse de grupo de pessoas, mas, o interesse de todos que deve ser resguardado pelo Estado. Não há qualquer previsão normativa no sentido de anunciar que o interesse público tem prevalência sobre o interesse privado. Apensar disto é possível, por meio de outras previsões legais, afirmar a existência de uma prevalência do interesse público e, especialmente, a existência de um dever da Administração Pública de zelar por sua

Rev. de de Direitos Fundamentais Nas Relações Do Trabalho, Sociais E Empresariais | e-ISSN: 2525-9903 | Goiânia| v. 5 | n. 1 | p. 18-34| Jan/Jun. 2019 
proteção. O interesse público deve assim orientar a atividade administrativa e legislativa. (MORAES, 2016, p.287).

A Fazenda Pública não pode manter-se distante de valores inerentes a um processo construído a partir de comportamentos cooperativos. É certo que esta análise é exigível, mas esta ideia ganha maior importância na medida em que é partícipe da administração pública, figurando como agente responsável por zelar pelo interesse público (MORAES, 2016, p.288). Assim, destaca-se que:

\begin{abstract}
$\mathrm{O}$ agir conforme o interesse público exige certo grau de coragem do agente público, que muitas vezes opta por medidas menos econômicas simplesmente para assim evitar o risco de ser acusado da prática favorecimento a determinada pessoa ou o risco de ser questionado perante os órgãos de fiscalização de suas atividades. O momento atual, no entanto, exigiu um aperfeiçoamento dos agentes públicos e as Fazendas Públicas estão cada dia melhor representadas em juízo e, também um pouco como reflexo disto, a cada instante novos diplomas legislativos surgem no sentido de autorizar a desistência de recursos, a possibilidade de acordos judiciais, o não ajuizamento de demandas de baixo valor (MORAES, 2016, p.288)
\end{abstract}

A celebração de negócios processuais que impliquem prejuízo aos interesses públicos, assim entendidos aqueles acordos que conduzam, ainda que indiretamente, a uma mutilação de verdadeiros direitos da Fazenda Pública, importando, deste modo, o prejuízo ao erário (MORAES, 2016, p 290).

A supremacia do interesse público determina privilégios jurídicos e o patamar de superioridade do interesse público sobre o particular. Esse princípio não está expresso no texto constitucional. Trata-se de um pressuposto lógico do convívio social (MARINELA, 2016, p.66)

A Administração Pública, de forma simples, tem como fundamento a concretização dos direitos dispostos nas Constituições, seja federal, seja estadual, e na legislação que rege a vida das pessoas residentes em determinado território. Se dá, primordialmente, com a prestação de serviços públicos nas mais diversas áreas e, na lição Cunha (2010, p. 588), é estruturada "para atingir o bem comum e assegurar um mínimo de direitos e garantias para o indivíduo", tendo "a incumbência intrínseca de executar serviços que revestem a matriz da necessidade e comodidade públicas, 
voltando seus esforços para o incremento e desenvolvimento de atividades que lhe são impostas pela sociedade" (OLIVEIRA, 2016, p.91)

Pertinente a clássica conceituação de José Cretella Júnior (1966, p. 27) de que a Administração não é só gênero do poder executivo, como também a complexa máquina administrativa, que movimenta a atividade desenvolvida por esse indispensável aparelhamento que possibilita ao Estado o preenchimento de seus fins. Pelo que, administração é a atividade que o Estado desenvolve, através de atos concretos e executórios, para a consecução direta, ininterrupta e imediata dos interesses públicos.

\section{TERCEIRIZAÇÃO: CONCEITUAÇÃO E HISTÓRICO}

A terceirização é um instituto oriundo da ciência da administração que visa a redução de custos bem como a especialização das atividades empresariais, na medida em que permite a maior concentração da empresa em sua atividade-fim, para a qual foi estabelecida, trespassando a outras empresas normalmente as atividades-meio, que não constituem o foco principal de sua existência. É certo que pode haver trespasse também de algumas atividades-fim (ZOCKUN, 2014 p. 21).

Logo, a essência da terceirização, à luz da Ciência da Administração, é repassar para outro (s) alguma (s) ou todas as atividades acessórias da empresa, de modo que ela possa se dedicar integralmente ao escopo de sua criação (SANTOS, 2014, p. 90).

A terceirização realiza-se de duas formas não excludentes. Na primeira, a empresa abandona a produção de bens e serviços empregados em sua atividade-fim e passa a adquiri-los de outra (s) empresa (s), gerando, desta forma, a desativação - parcial ou total - de seções que dantes funcionavam no interior da empresa. A outra forma é a contratação de uma ou mais empresas para realizar, dentro da "empresa-mãe", atividades anteriormente executadas por trabalhadores contratados diretamente. Essa segunda forma de terceirização pode referir-se tanto a atividades-fim como a atividadesmeio (ZOCKUN, 2014, p. 22).

Rev. de de Direitos Fundamentais Nas Relações Do Trabalho, Sociais E Empresariais | e-ISSN: 2525-9903 | Goiânia| v. 5 | n. 1 | p. 18-34| Jan/Jun. 2019 


\subsection{Evolução histórica}

A terceirização surgiu após a Revolução Industrial. No começo do século XX os Estados Unidos e a Alemanha despontaram como grandes potências industriais. O setor metalúrgico era o que continha o maior número de trabalhadores, e a indústria automobilística foi pioneira na criação do processo de produção (ZOCKUN, 2014, p. 23)

Assim houve uma mobilização pela reivindicação de melhores condições de trabalho, notadamente no final do século XIX e início do século XX, passando-se a exigir do Estado uma intervenção direta na sociedade, para a garantia de condições mínimas de existência digna do cidadão.

O Estado do Bem-Estar Social é aquele que se instituem obrigações positivas para que o Estado opere em prol de seus cidadãos, corrigindo os naturais desvios do individualismo clássico liberal, para que se possa alcançar a verdadeira justiça social. Com isso, o Fordismo considerado o modelo de gerenciamento adotado por Henry Ford foi criado por Frederic Wislow Taylor (1856-1915), engenheiro norte-americano. Já o método de Taylor consistia em executar uma linha de produção em série, em que todo o trabalho era segmentado em diversas funções, a serem desempenhadas por trabalhadores de forma sequencial e repetitiva. Por várias décadas o sistema criado por Ford (fordismo) funcionou com perfeição. Entretanto, a partir da década de 1970 chegou-se a um esgotamento, em função dos limites da expansão econômica. O mercado interno dos Países industrializados ficou próximo da saturação em relação à comercialização de automóveis. Houve uma desaceleração nos ganhos com a produtividade, ademais os investimentos no desenvolvimento de máquinas para aumentar a produtividade e o crescente custo da mão de obra restringiram as margens de lucro das indústrias (ZOCKUN, 2014, p. 26).

Seguindo o percurso da história, o volvismo foi o primeiro método criado na Suécia, na década de 1960, pelo engenheiro da Volvo, Emti Chavanmco, e ficou conhecido como volvismo. O volvismo é caracterizado pela produção de bens exclusivos, em pequena escala, mas com alto valor agregado. Sua estratégica combina

Rev. de de Direitos Fundamentais Nas Relações Do Trabalho, Sociais E Empresariais | e-ISSN: 2525-9903 | Goiânia| v. 5 | n. 1 | p. 18-34| Jan/Jun. 2019 
os seguintes elementos: os requisitos e demandas do mercado, os aspectos tecnológicos os imperativos do dinâmico processo de transformação da organização do trabalho e as instáveis condições da reestruturação da indústria. Operando num mercado de trabalho complexo, a Volvo internacionaliza a produção e democratizou a vida no trabalho (ZOCKUN,2014, p. 27).

$\mathrm{Na}$ construção temporal dos modelos de gerenciamento administrativo, ainda, destaca-se o toyotismo que foi implantado pelo especialista em produção Taiichi Ohno, na fábrica da Toyota, e com os avanços da globalização, rapidamente tornou-se o parâmetro mundial de sistema de produção flexível. Inicialmente os trabalhadores da Toyota eram agricultores, mas com as ideais de Onho os empregados foram realizando cursos e se especializando em produção veicular, tendo conhecimento de toas as etapas do sistema de produção. O toyotismo extingue o trabalho repetitivo, ultrassimplificado, desmotivante, embrutecedor. Este modelo possuía vários fornecedores principais, em grupos funcionais, que, por sua vez, seguiam igual critério com seus respectivos subfornecedores, compondo, desta forma, uma estrutura piramidal. Vê-se, pois, que a cadeia produtiva era dividida entre diversos fornecedores. O resultado final era um produto competitivo, com custo e preço inferiores aos realizados por Ford e maior adaptabilidade ao gosto do consumidor (ZOCKUN, 2014, p. 28).

O Brasil, acompanhando a tendência mundial, deu início à terceirização material, na década de 1970, também por meio do setor automobilístico. O modelo, entretanto, sofreu, nos anos 1980, forte resistência sindical e das próprias administrações das empresas, habituadas com plano centralizados de organização e gerência do trabalho. Contudo, nos anos de 1990 a terceirização material espraiou-se para todos os setores produtivos. A intensificação do fenômeno da globalização impulsionou a abertura da economia ao Exterior, realizada de forma abrupta e dissociada de políticas industriais e agrícola. Esse processo ocorreu em um ambiente de intensa retratação econômica, durante o governo Fernando Collor, e se prolongou até o final da década. Desta forma, a terceirização foi alavancada (i) pela necessidade imperativa de uma reestruturação produtiva par alcançar patamares de produtividade que garantissem a competitividade e (ii) pela longa recessão da economia brasileira (ZOCKUN, 2014, p. 29). 
No tocante a terceirização na administração pública, pode-se destacar que o surgimento, inicialmente, se deu por meio do Decreto-lei 200/1967, em seu art. 10, $\S 7^{\circ}$, que estabelece:

\begin{abstract}
Art. 10. A execução das atividades da administração Federal deverá ser amplamente descentralizada.

(...).

$\S 7^{\circ}$. Para melhor desincumbir-se das tarefas de planejamento, coordenação, supervisão e controle e com o objetivo de impedir o crescimento desmesurado da máquina administrativa, a Administração procurará desobrigar-se da realização material de tarefas executivas, recorrendo, sempre que possível, à execução indireta, mediante, contrato, desde que exista, na área, iniciativa privada suficientemente desenvolvida e capacitada a desempenhar os encargos de execução.
\end{abstract}

Prosseguindo com a ideia de descentralização das atividades da alçada da administração pública, em 1970 foi editada a Lei 5.645, que fixou diretrizes para a classificação de cargos do Serviço Civil da União e das autarquias federais e, em seu art. $3^{\circ}$, parágrafo único, estabeleceu que as atividades relacionadas com transporte, conservação, custódia, operação de elevadores, limpeza e outras assemelhadas serão de preferência, objeto de execução indireta, mediante contrato, de acordo com o art. 10, § $7^{\circ}$, do Decreto-lei n. ${ }^{\circ}$ 200, de 25 de fevereiro de 1967 (ZOCKUN, 2014, p. 32).

O autor Couto e Silva, 2003, esclarece que no Brasil os primeiros ensaios privatizantes apareceram no governo do General João Figueiredo (1981-1984, com a edição do Decreto 86.215, de 15.7.1981), que privatizou 20 empresas que estavam sob o controle da União (entre elas: Riocel, América Fabril, Cia. Química Recôncavo). No Governo do Presidente José Sarney (1985-1989) as privatizações recaíram sobre cerca de 18 empresas (entre elas a Cia. Brasileira de Cobre, a Caraíba Metais, a Aracruz e a Celulose Bahia). Nesse mesmo período foi editado o Decreto 95.886, de 29.3.1988, que dispunha sobre o Programa Federal de Desestatização. Com efeito, a ideia de "enxugamento" do Estado foi defendida com grande entusiasmo, devendo o Estado estar restrito a atividades mínimas - o que fez com que a terceirização ganhasse força e fosse utilizada em larga escala pela Administração Pública.

Assim, o grande marco da terceirização no Brasil, no que tange à administração pública, foi o plano de Reforma do Aparelho Estatal, que de forma desmedida passou a Rev. de de Direitos Fundamentais Nas Relações Do Trabalho, Sociais E Empresariais | e-ISSN: 2525-9903 | Goiânia| v. 5 | n. 1 | p. 18-34| Jan/Jun. 2019 
retirar da alçada da administração pública setores de suma importância para a cidadania e a segurança do País. A proposição adotada foi no sentido de que "menos é mais" - ou seja: quanto menor for o Estado, mais eficiente e melhor ele será (ZOCKUN, 2014, p.34).

\section{DANO EXISTENCIAL NAS RELAÇÕES DE TRABALHO}

O dano existencial também denominado por dano a existência do trabalhador, decorre da conduta patronal que impossibilita o emprego de se relacionar e de conviver em sociedade por meio de atividades recreativas, afetivas, culturais, esportivas, sociais e de descanso, que lhe traria bem-estar físico e psíquico, ou que impede de executar, de prosseguir ou mesmo de recomeçar seus projetos de vida, impedindo seu crescimento pessoal e profissional (BOUCINHAS FILHO E ALVARENGA, 2010, p.12).

Dessa forma, o dano existencial corresponde a qualquer dano que o trabalhador venha a sofrer decorrente das suas atividades realizadas no âmbito do trabalho. Parte da doutrina civil brasileira, inspirada na experiência dogmática e jurisprudencial italiana, pioneira no trato jurídico da dignidade humana e sua incidência nas relações privadas, visto que, a Constituição Italiana foi a primeira a reconhecer juridicamente a dignidade como fundamento central do sistema, passou a refletir sobre questões de dano existencial (MOLILA, 2015, p. 26).

Conforme o autor Almeida Neto, 2012, o ser humano tem o direito fundamental constitucionalmente assegurado de fazer ou deixar de fazer o que bem entender, desde que, evidentemente respeitado o direito do próximo e os limites legais, não podendo ser molestado por quem quer que seja, em qualquer aspecto de sua vida. Tem a pessoa o direito às suas expectativas, aos seus anseios, aos seus projetos, aos seus ideais, desde os mais singelos até os mais grandiosos.

Rev. de de Direitos Fundamentais Nas Relações Do Trabalho, Sociais E Empresariais | e-ISSN: 2525-9903 | Goiânia| v. 5 | n. 1 | p. 18-34| Jan/Jun. 2019 
Nas palavras de Bebber (2009), toda lesão que comprometa a liberdade de escolha e frustra o projeto de vida que a pessoa elaborou como ser humano diz respeito ao dano existencial nas relações trabalhistas. Fala-se existencial porque o impacto gerado pelo dano provoca um vazio existencial na pessoa que perde a fonte de gratificação vital, que seria o prazer em conviver e vivenciar seus projetos de vida. Por projeto de vida compreende-se o destino escolhido pela pessoa, o que se decidiu fazer com a sua vida. O ser humano por natureza, busca extrair o máximo das suas potencialidades. O fato injusto que frustra esse destino e obriga a pessoa a resignar-se com o seu futuro é chamado de dano existencial. Assim conforme jurisprudência do TST - RECURSO DE REVISTA RR 10347420145150002 (TST),

Ementa: INDENIZAÇÃO POR DANO EXISTENCIAL. JORNADA DE TRABALHO EXTENUANTE. O dano existencial consiste em espécie de dano extrapatrimonial cuja principal característica é a frustração do projeto de vida pessoal do trabalhador, impedindo a sua efetiva integração à sociedade, limitando a vida do trabalhador fora do ambiente de trabalho e o seu pleno desenvolvimento como ser humano, em decorrência da conduta ilícita do empregador. O Regional afirmou, com base nas provas coligidas aos autos, que a reclamante laborava em jornada de trabalho extenuante, chegando a trabalhar 14 dias consecutivos sem folga compensatória, laborando por diversos domingos. Indubitável que um ser humano que trabalha por um longo período sem usufruir do descanso que the é assegurado, constitucionalmente, tem sua vida pessoal limitada, sendo despicienda a produção de prova para atestar que a conduta da empregadora, em exigir uma jornada de trabalho deveras extenuante, viola o princípio fundamental da dignidade da pessoa humana, representando um aviltamento do trabalhador. O entendimento que tem prevalecido nesta Corte é de que o trabalho em sobrejornada, por si só, não configura dano existencial. Todavia, no caso, não se trata da prática de sobrelabor dentro dos limites da tolerância e nem se trata de uma conduta isolada da empregadora, mas, como afirmado pelo Regional, de conduta reiterada em que restou comprovado que a reclamante trabalhou em diversos domingos sem a devida folga compensatória, chegando a trabalhar por 14 dias sem folga, afrontando assim os direitos fundamentais do trabalhador. Precedentes. Recurso de revista conhecido e desprovido.

Nesse entendimento, reconhece-se que a frustração ao projeto de vida decorrente da conduta patronal ilegal gera os danos existenciais no trabalhador (NASCIMENTO, 2014, p. 65).

Rev. de de Direitos Fundamentais Nas Relações Do Trabalho, Sociais E Empresariais | e-ISSN: 2525-9903 | Goiânia| v. 5 | n. 1 | p. 18-34| Jan/Jun. 2019 


\section{CONSIDERAÇÕES FINAIS}

Com relação ao objetivo do trabalho que se propôs a analisar as implicações do dano existencial decorrente da terceirização na administração pública, haja vista que o referido dano passa a ser compreendido a partir da conduta patronal sistemática em impor jornadas de trabalho além dos limites legais, causando verdadeira anulação do indivíduo que deixa de vivenciar atividades recreativas, culturais, esportivas, perdendo considerável parte do convívio familiar, sendo reduzido a mera ferramenta de trabalho, verifica-se que a terceirização como instrumentalização através de recursos humanos e materiais para a prestação de quaisquer de suas atividades aprovisiona-se, compulsoriamente dos agentes e dos recursos materiais necessários ao implemento de todos os seus cometimentos.

Depreende-se que não importa se ocorreu compensação pelo trabalho extra, em forma de pagamento financeiro ou outro tipo de recompensa, pois o dano existencial implica no distanciamento e desperdício de tempo com os familiares e realizações pessoais e profissionais em face da jornada de trabalho excessiva. Tempo, que não volta para satisfação dos projetos idealizados e não realizados por causa da sistemática patronal em exigir tempo e afastamento dos planejamentos individualizados pelos trabalhadores.

Quanto a problemática do trabalho que se lançou na busca de reflexões sobre as implicações do dano existencial causado pela terceirização de atividade da administração pública, uma vez que determinados fatores causam verdadeira anulação do indivíduo. Como resposta, ao longo da pesquisa, constatou-se que o fator decisivo para a caracterização do dano existencial é verificar o caso concreto, se está diante de uma violação direta da dignidade humana. A dignidade da pessoa humana é o fundamento moderno do Estado Democrático de direito e os dos direitos humanos ao reconhecer que o trabalho excessivo e reiterado, até o limite legal, ainda que haja recompensa ou pagamento da jornada extra, importa em dano existencial na medida que retira do trabalhador o seu direito de exercício de liberdade de autodeterminar-se, de

Rev. de de Direitos Fundamentais Nas Relações Do Trabalho, Sociais E Empresariais | e-ISSN: 2525-9903 | Goiânia| v. 5 | n. 1 | p. 18-34| Jan/Jun. 2019 
poder escolher relacionar-se ou não no âmbito familiar e social, bem como prejudicando seus projetos de vida fora do ambiente de trabalho.

Quanto a terceirização que significa pura e simplesmente, passar para particulares tarefas que vinham sendo desempenhadas pelo Estado, estar-se-ia diante de uma relação trilateral, composta pelo trabalhador, o intermediador de mão de obra e o tomador de serviços: o trabalhador presta serviços que serão aproveitados pelo tomador, mas quem o dirige e assalaria é o intermediador de mão de obra, com o qual contrata, e recebe a remuneração do tomador. Em face dessa situação, tem-se a ocorrência do dano existencial, haja vista que o trabalhador mesmo desempenhando suas atividades no interior da administração pública, não o caracteriza servidor público, mas sim um trabalhador atormentado pelo temor da rescisão contratual e pelo baixo rendimento salarial.

Não obstante verifica-se que em face da terceirização ou precarização da mão de obra, o trabalhador torna-se objeto de produção, o que afasta o viés da pessoa humana. Sua mão de obra pode ser substituída a qualquer momento. Fato que nos remete a teoria do valor de troca, em que pese a coisificação do ser humano enquanto trabalhador. Precisamente, o dano existencial no âmbito da administração pública, ocorre pelo distanciamento das atividades e pela jornada excessiva de trabalho que são próprias da administração, tomemos como exemplo, o poder de polícia - que é a atividade de condicionamento da liberdade e da propriedade dos indivíduos, com fundamento na supremacia geral da administração sobre os administrados, na forma da lei, a fim de compatibilizá-las com o bem-estar social; a prestação de serviços públicos que são atividades (consistentes na prestação de utilidade ou comodidade material) destinadas a satisfazer a coletividade em geral, e que por sua vez, limitam o trabalhador terceirizado e prioriza o servidor de carreira.

A jornada excessiva de trabalho no âmbito da administração pública decorre de cobranças para o cumprimento de atividades desempenhadas além do estabelecido no contrato de trabalho, o que caracteriza o dano existencial e a forma diferenciada de tratamento entre os administrados.

\section{REFERÊNCIAS}

Rev. de de Direitos Fundamentais Nas Relações Do Trabalho, Sociais E Empresariais | e-ISSN: 2525-9903 | Goiânia| v. 5 | n. 1 | p. 18-34| Jan/Jun. 2019 
AlMEIDA NETO, Amaro Alves de. Dano existencial - A tutela da dignidade da pessoa humana. Revista síntese de direito civil e processual 12/80, nov - dez, 2012, p. 33.

BEBBER, Júlio Cesar. Danos extrapatrimonais (estético, biológico e existencial breves considerações. Revista LTr, Vol 73, n. 1, p. 28, jan, 2009.

BOUCINHAS FILHO, Jorge Cavalcanti e ALVARENGA, Rubia Zanotelli de. O dano existencial e o direito do trabalho. 2010. Disponível em http://www.lex.com.br/doutrina_24160224_O_DANO_EXISTENCIAL_E_O_DIREIT O_DO_TRABALHO.aspx. Acesso em 09 de jul. de 2017.

CUNHA, Leonardo Carneiro da. A fazenda pública em juízo. 13. ed., totalmente reformulada - Rio de janeiro: Forense, 2016.

BRANCO, Paulo Gustavo Gonet; COELHO, Inocêncio Mártires; MENDES, Gilmar Ferreira. Curso de Direito Constitucional. 3. ed. rev. e atual. São Paulo: Saraiva, 2008.

BRASIL. Constituição (1988). Constituição da República Federativa do Brasil, de 5 de outubro de 1988.

BRASIL. TST - RECURSO DE REVISTA RR 10347420145150002 (TST). Publicado em 13.11.2015.

Disponível

em

https://www.jusbrasil.com.br/jurisprudencia/busca?q=EXISTENCIAL. Acessado em 01 de jul de 2017.

CARVALHO FILHO, Jose dos Santos. Manual de direito administrativo, 21, ed. Rio de Janeiro: Lumen Juis, 2009, p.10

COUTO E SILVA, Almiro do. Privatização no Brasil e o novo exercício de função públicas por particulares: serviço à brasileira?. Revista da procuradoria geral do estado (Rio Grande do Sul) 27/209-237. N 57. Porto Alegre Procuradoria Geral do Estado do Rio Grande do Sul, 2003.

CUNHA, Leonardo Jose Carneiro da. O regime processual das causas repetitivas, In: Revista de Processo, vol. 179, ano 35, p. 139 - 174, São Paulo: editora Revista dos Tribunais, Jan. 2010.

CUNHA, Leonardo Carneiro da; RODRIGUES, Marco Antônio (Coord.). Fazenda Pública. $2^{\circ}$ ed. ver, ampl e atual. - Salvador: Juspovim, 2016. 
Cretela júnior, José. Empresa Pública. São Paulo: universidade, 1996.

GASPARINI, Diógenes. Direito administrativo. $9^{\circ}$ ed, São Paulo: Saraiva, 2004, p. 42 NASCIMENTO, Sônia Mascaro. Dano existencial nas relações de trabalho. Revista LTr, vol 78, n. 8, p, 965-972, ago, 2014.

NUNES, Claudia Sofia Henriques. O contrato de trabalho em funções públicas. Coimbra, 2014.

NUSSBAUM, Martha C. Fronteiras da justiça: deficiência, nacionalidade, pertencimento à espécie. Tradução de Susana de Castro. - São Paulo: WMF Martins, 2013. - (Biblioteca jurídica WMF).

MARINELA, Fernanda. Direito administrativo. 10 ${ }^{\mathrm{a}}$ ed. São Paulo: Saraiva, 2016.

MOLILA, André Araújo. Dano existencial por jornada de trabalho excessiva critérios objetivos. Revista dos Tribunais, vol. 164, p. 15-43, 2015.

MORAES, José Roberto de. Prerrogativas processuais da Fazenda Pública. In: SUNDFELD, Carlos Ari, BUENO, Cassio Scarpinella (coords). Direito processual público: a Fazenda Pública em juízo. São Paulo: Malheiros, 2000.p.69.

OLIVEIRA, Weber Luiz de. Precedentes Judiciais na Administração Pública: Limites e Possibilidades de Aplicação. Salvador: JusPodivm. Coleção Eduardo Espínola, 2016.

SANTOS, Diogo Palau Flores dos. Terceirização de serviços pela administração pública - Estudo da Responsabilidade Subsidiaria. 2a ed. São Paulo: Saraiva, 2014.

SARMENTO, Daniel Antonio de Moraes. Direitos Fundamentais e Relações Privadas. 2.ed. Rio de Janeiro: Lumen Juris, 2006.

ZOCKUN, Carolina Zancaner. Da terceirização da Administração Pública. São Paulo: Malheiros, 2014. 